\title{
Induced systemic resistance against rice grassy stunt virus - a promising field for ecological rice production
}

\author{
Kích kháng luu dẫn đối với bệnh vàng lùn trên lúa - triển vọng trong việc sản \\ xuất lúa theo hướng sinh thái
}

Research article

Le, Thanh Toan*; Luong, Van Dien; Ngo, Thi Thuy Nhien; Pham, Van Kim

College of Agriculture and Applied Biology, Can Tho University, 3/2 Str., Can Tho city, Vietnam

\begin{abstract}
Most rice protection methods have currently used toxic chemicals to control pathogens and pests, which leads to environmental pollution. Systemic acquired resistance (SAR) taking advantage of natural defence reaction of plants could be proposed as an alternative, ecologically friendly approach for plant protection. Its application into rice production could minimize the chemicals quantity used and could contribute to the decrease of environmental pollution and the development of sustainable agriculture. The research was conducted to select the most effective chemical and suitable method to improve the health of rice plants infected by grassy stunt disease in net-house of Can Tho University. SAR chemicals were used at very low concentrations (in mM). Results showed that the height of rice plants treated with SAR chemicals was higher than that of plants untreated. Besides, the number of diseased plants was reduced and the ratio of firm grain and yield increased when plants were applied by SAR. Among the used substances, oxalic acid provided the best systemic acquired resistance. With oxalic acid, seed soaking was better than seed coating in systemic acquired resistance against rice grassy stunt disease.
\end{abstract}

Hầu hết các phuơng pháp sản xuất lúa hiện nay đều sử dụng các hóa chất độc hại trong việc phòng trù̀ bệnh và côn trùng gây hại, nên dẫn đển ô nhiễm môi truờng. Kích thích tính kháng lưu dẫn giúp kich hoạt co chế tụ nhiên kháng bệnh của cây có thể là giải pháp bảo vệ thực vật thay thế an toàn với môi truờng. Việc úng dụng tiến bộ này vào trong sản xuất lúa có thể làm giảm lương hóa chất sủ dung, đóng góp vào việc giảm thiểu ô nhiễm môi trường và sự phát triển của một nền nông nghiệp bền vũng. Nghiên cưu đã được thực hiện tại nhà luới truờng Đại học Cần Tho để tuyển chọn hóa chất và phuoong pháp sử dưng hóa chất để tăng cuờng sức khỏe giúp cây lúa vuoơt qua bệnh vàng lùn. Hóa chất kích kháng được sủ dung ở một nồng độ rất thấp (đơn vị là $m M$ ). Kết quả cho tháy chiều cao cây lúa khi xử lý chất kích kháng tốt hơn so đối chứng không xủ lý. Bên canh đó, số cây lúa nhiễm bệnh giảm, tỉ lẹ hạt chắc và năng suất tăng khi cây lúa được xử lý với chất kích kháng. Trong số các chất kích kháng đã sư dụng, acid oxalic cho hiệu quả vuoọt trội. Với chất acid oxalic, phuoong pháp ngâm hạt cho hiệu quả kich kháng tốt hơn phuơng pháp áo hạt.

Keywords: ecological rice production; systemic acquired resistance; rice grassy stunt disease

\section{Introduction}

Rice production in Vietnam is largely based on the use of fungicides, bactericides and insecticides - chemical compounds toxic to disease agents or pests. However, the harmful effect of these chemicals on the environment and human health demands the researches for new harmless means of disease control. Induced plant resistance against pathogen infection has been described for more than 100 years (early reviewed by Chester, 1933; Mahy and Van
Regenmortel, 2010). Exploiting the plant potential to resist pathogens, the induced resistance may diminish the use of toxic chemicals to disease and pest control, and thus could be proposed as an alternative, non-toxic and ecologically friendly approach for plant protection and hence for sustainable agriculture (Heil, 2001; Edreva, 2004).

Most of the work on the induced resistance, however, was with dicotyledonous plants. Considering the economic 
importance of monocotyledonous crop plants, the number of studies on this Order is comparatively small (Steiner and Schonbeck, 1995).

Worldwide, many scientists have successfully conducted their research by using systemic acquired resistance (SAR) to control plant viral diseases. Ghoshroy et al. (1998), Naylor et al. (1998), Chivasa and Carr (1998), Anfoka (2000), Dong and Beer (2000), Chirkov et al. (2001), Ahn et al. (2005), Mayers et al. (2005), Faheed and Mahmoud (2006), Man-dal et al. (2007) and Sudhakar et al. (2007) had successfully used chemicals such as cadmium, salicylic acid, 2,6-dichloroisonicotinic acid, antimycin A, riboflavin, vitamin B1, chitosan, benzo-(1,2,3)-thiadizole-7-carbothioic-S-methyl ester, kinetin, acibenzolar-S-methyl and ozone to induce plants against Tobacco mosaic virus, Potato virus X, Cucumber mosaic virus, Tobacco necrotic virus, Tomato spotted wilted virus. Raupach et al. (1996), Murphy et al. (2000), Zehnder et al. (2000), Elbadry et al. (2006) and Al-Ani et al. (2011) succeeded in using plant growth-promoting rhizobacteria (PGPR), Pseudomonas fluorescence and Azospirillum irakense to induce resistance in plants against Cucumber mosaic virus, Tomato mottle virus, Bean yellow dwarf virus. In rice, induction of resistance by applying biotic and abiotic inducers have been demonstrated by Iwano (1987), Smith and Metraux (1991), Steiner and Schonbeck (1995), Du et al. (2001), Nandakumar et al. (2001), Thuy et al. (2004), Kagale (2004), Saikia et al. (2006), Taheri (2010), Pal et al. (2011), Chithrashree et al. (2011) and Govindappa et al. (2011). Following these SAR achievements with viral diseases in tobacco, papaya, chilli, potato, cucumber etc; SAR method could be applied to rice grassy stunt disease.

The area of rice production in Vietnam is about 7.5 millions of hectares. The epidemics of rice grassy stunt virus (RGSV) and rice ragged stunt virus (RRSV) have begun to cause serious damage in Vietnam since 2006. According to Vietnam Plant Protection Department (2006), rice area seriously infected by RGSV and RRSV was 43,887 ha. Crop loss in the Mekong Delta was approximately 428,000 tons due to the damage caused by brown plant hopper (BPH), RGSV and RRSV. The farmers used a lot of chemicals to kill BPH and keep rice plants' vigour. Only 20-30\% of chemicals (by quantity) reached the goal or was kept by plants; the remaining was useless and accumulated in the soil. The unused chemicals will pollute the soil, water, and even groundwater. This epidemic has continued to do damage to Vietnam's rice production, affect national food security and rice export. Many methods for reducing rice grassy stunt disease (RGSD) and rice ragged stunt disease (RRSD) have been applied in many places. The method of sowing at a time in accordance with lowest population of migratory BPH helped the farmers in restricting damage of viral diseases. In addition, protecting young rice plants also had a part in reducing the damage. However, there is no rice variety that can be tolerant of RGSV and RRSV, the rice price is at high level, the farmers grow overlapping crops and thus RGSD and RRSD will always occur in the field, at different ratios. In this situation, to keep farmers "living" together with RGSD, RRSD as well as to avoid another outbreak of epidemics in the future, systemic acquired resistance is considered to be a feasible and cheap method, as well as safe to the environment. If successful, the method can be introduced to farmers to decrease damage when they cannot avoid BPH at the beginning of crop. To reach this aim, the research was conducted to find the most effective chemicals in SAR to RGSD for the rice plants infected early (at 7 days) after sowing. Further on, the paper focuses on finding the suitable way to use the effective chemicals.

\section{Materials and methods}

The experiment was conducted in the net-house of Plant Protection Department, College of Agriculture and Applied Biology at Can Tho University. The rice variety was a BPH susceptible variety that was widely cultivated in the Mekong Delta.

RGSD source was collected in Can Tho city and purified to separate from RRSD, then used for the experiment. Clean BPHs used for transmitting RGSD were collected in the field and their eggs were laid in pickerelweed's sheaths (Momochoria vaginalis). The eggs hatched, the BPH larvae did not held RGSV and RRSV (rechecking by Enzyme-linked Immunosorbent Assay - ELISA). BPH larvae 1 to 2 took RGSV in grassy stunt rice for 2 days and then they were fed on healthy rice to be latent. After being latent RGSV, the BPH larvae 4 to 5 (infected with RGSV) were used for the experiment.

The screening of potential chemicals was conducted with 10 types of chemicals, three concentrations for each chemical (data not shown). The SAR chemicals chosen were $\mathrm{CuCl}_{2}(0.05 \mathrm{mM})$, oxalic acid $(0.5 \mathrm{mM}), \mathrm{K}_{2} \mathrm{HPO}_{4}$ (20mM). The experiment of chemicals' selection was carried out with randomized complete design, 10 replications, 6 rice plants/replication, and 6 treatments namely (1) $\mathrm{CuCl}_{2}$; (2) oxalic acid; (3) $\mathrm{K}_{2} \mathrm{HPO}_{4}$; (4) mixing of $\mathrm{CuCl}_{2}$ and $\mathrm{K}_{2} \mathrm{HPO}_{4}$; (5) a control with diseased rice plants and (6) a control with healthy rice plants. The SAR chemicals were $\mathrm{CuCl}_{2}$ (concentration is $0.05 \mathrm{mM}$ ), oxalic acid $(0.5 \mathrm{mM}), \mathrm{K}_{2} \mathrm{HPO}_{4}(20 \mathrm{mM})$. The seed was soaked for 24 hours and the leaf was sprayed at 10, 20, 30 and 40 days after sowing (DAS).

The experiment of oxalic acid's usage was performed with randomized complete design, 5 replications, 6 rice plants/replication, and 9 treatments namely (1) seed coating; (2) seed coating and leaf spraying at 10, 20, 30 and 40 DAS; (3) seed soaking; (4) seed soaking and leaf spraying at 10 DAS; (5) seed soaking and leaf spraying at 20 DAS; (6) seed soaking and leaf spraying at 10, 20 and 30 DAS; (7) seed soaking and leaf spraying at 10, 20, 30 and 40 DAS; (8) a control with infected rice plants and (9) a control with healthy rice plants. The SAR chemical was oxalic acid $(0.5 \mathrm{mM})$.

For all experiments, RGSD was transmitted to rice plants at 7 DAS with $3 \mathrm{BPH}$ larvae, 4 to 5 for each tiller. The BPH had transmitted for 2 days and then was killed. After transmitting, the rice plants were put in the net-house. The data collected include the ratio of infected plants and the length of rice plant. Yield/pot and elements of yield were recorded after harvesting. The elements of yield included 
the effective tillers per pot (effective tiller: tiller has floccules) and weight of firm grain per pot. The data was analysed by using MSTATC software.

\section{Results and discussion}

\subsection{The experiment of chemicals' selection to rice grassy stunt disease}

The data presented in Table 1 shows that the control with infected rice plants had a high ratio of diseased plants (68.3\%). This result proved that experiment's inoculation was good. Meanwhile, ratios of diseased plant in systems treated by chemicals were lower and significantly different to the control with healthy rice plants. This result indicates that the chemicals had an important effect in reducing the RGSD compared to the control with infected rice plants (without treating chemicals). Among the treated samples, the chemicals had the same ability in decreasing ratio of diseased plants. For the average latent time, there are no significant differences between the infected treatments. This implies that the chemicals did not affect the average latent time. Recording the beginning time for diseased plants' death, the control with diseased rice plants was 21 days after inoculation (DAI). Treatment treated with $\mathrm{K}_{2} \mathrm{HPO}_{4}$ was $43 \mathrm{DAI}$, the treatment treated with $\mathrm{CuCl}_{2}$ and $\mathrm{K}_{2} \mathrm{HPO}_{4}$ was 42 DAI and treatment treat- ed with oxalic acid was 60 DAI. For this parameter, the treatments oxalic acid, $\mathrm{K}_{2} \mathrm{HPO}_{4}$ and mixing of $\mathrm{CuCl}_{2}$ and $\mathrm{K}_{2} \mathrm{HPO}_{4}$ were effective SAR chemicals; among them, oxalic acid was the most valuable chemical that can prolong rice's life. There is no data of this parameter on the control with healthy rice plants.

At $35 \mathrm{DAI}$, the treatments treated by chemicals $\left(\mathrm{CuCl}_{2}\right.$ or $\mathrm{K}_{2} \mathrm{HPO}_{4}$ or their mixing or oxalic acid) had the increasing rate of height in significant difference in comparison to the control with diseased rice plants. Therefore, induced chemicals can maintain the height of rice plant.

The data presented in Table 1 indicates a significant difference of effective tillers per pot between diseased and non-diseased treatments. The number of effective tillers per pot in treatments infected virus was 21.5 to 34.9 , while the number of effective tillers per pot in the control with healthy rice plants was 52.3. The weight of firm grain per pot of chemical's treatments was equivalent to the control with healthy rice plants, but significantly different in comparison to the control with diseased rice plants. The weight of firm grain per pot of these treatments was $25.40 \mathrm{~g}\left(\mathrm{CuCl}_{2}\right), 27.63 \mathrm{~g}\left(\mathrm{~K}_{2} \mathrm{HPO}_{4}\right), 28.01 \mathrm{~g}$ $\left(\mathrm{CuCl}_{2}\right.$ and $\mathrm{K}_{2} \mathrm{HPO}_{4}$ ), $33.27 \mathrm{~g}$ (oxalic acid), $12.11 \mathrm{~g}$ (the control with diseased rice plants) and $31.13 \mathrm{~g}$ (the control with healthy rice plants).

Table 1. The effect of chemicals' treatment to infected rice plants' growth and yield

\begin{tabular}{|c|c|c|c|c|c|c|}
\hline Treatments & $\begin{array}{l}\text { Ratio of in- } \\
\text { fected plants } \\
(\%)\end{array}$ & $\begin{array}{l}\text { Average } \\
\text { latent time } \\
\text { (DAI) }\end{array}$ & $\begin{array}{l}\text { Beginning } \\
\text { time for in- } \\
\text { fected plants } \\
\text { death (DAS) }\end{array}$ & $\begin{array}{l}\text { Increasing } \\
\text { rate of } \\
\text { height at } 35 \\
\text { DAI }(\%)\end{array}$ & $\begin{array}{l}\text { Effective } \\
\text { tillers/pot } \\
\text { (tiller) }\end{array}$ & $\begin{array}{l}\text { Weight of } \\
\text { firm grain } \\
\text { /pot (g) }\end{array}$ \\
\hline $\mathrm{CuCl}_{2} 0.05 \mathrm{mM}$ & $35.0 \mathrm{~b}$ & $13.72 \mathrm{~b}$ & 20 & $23.6 \mathrm{~b}$ & $30.1 \quad b c$ & $25.40 \mathrm{a}$ \\
\hline $\mathrm{K}_{2} \mathrm{HPO}_{4} 20 \mathrm{mM}$ & $26.7 \mathrm{~b}$ & $13.75 \mathrm{~b}$ & 43 & $23.2 \mathrm{~b}$ & $21.5 \quad \mathrm{c}$ & $27.63 \mathrm{a}$ \\
\hline $\begin{array}{l}\mathrm{CuCl}_{2} 0.05 \mathrm{mM}+ \\
\mathrm{K}_{2} \mathrm{HPO}_{4} 20 \mathrm{mM}\end{array}$ & $36.7 \mathrm{~b}$ & $12.55 \mathrm{~b}$ & 42 & $19.4 \mathrm{~b}$ & $26.2 \mathrm{bc}$ & $28.01 \mathrm{a}$ \\
\hline Oxalic acid $0.5 \mathrm{mM}$ & $26.7 \mathrm{~b}$ & $13.75 \mathrm{~b}$ & 60 & $29.8 \mathrm{~b}$ & $34.9 \quad \mathrm{~b}$ & $33.27 \mathrm{a}$ \\
\hline $\begin{array}{l}\text { Control with dis- } \\
\text { eased rice plants }\end{array}$ & $68.3 \mathrm{c}$ & $12.78 \quad b$ & 21 & $0.0 \mathrm{c}$ & $27.0 \mathrm{bc}$ & $12.11 \quad b$ \\
\hline $\begin{array}{l}\text { Control with healthy } \\
\text { rice plants }\end{array}$ & $0.0 \mathrm{a}$ & $0.00 \mathrm{a}$ & - & $58.0 \mathrm{a}$ & $52.3 \mathrm{a}$ & $31.13 \mathrm{a}$ \\
\hline Significant level & $*$ & $*$ & - & $*$ & $*$ & $*$ \\
\hline CV (\%) & 28.4 & 36.5 & - & 35.1 & 13.2 & 16.6 \\
\hline
\end{tabular}

Numbers followed by the same letter do not differ significantly according to Duncan's multiple range test at $\mathrm{P}=0.05$

*: differ significantly according to Duncan's multiple range test at $\mathrm{P}=0.05$

-: do not record the parameter on healthy rice plant

The chemical's treatments such as $\mathrm{CuCl}_{2}, \mathrm{~K}_{2} \mathrm{HPO}_{4}$, mixing of $\mathrm{CuCl}_{2}$ and $\mathrm{K}_{2} \mathrm{HPO}_{4}$, and oxalic acid, at used concentrations in this experiments, had the ability in maintaining the rice height better than the control with diseased rice plants. In addition, these chemicals also helped the rice plant in decreasing the ratio of diseased plants, prolonging the survival time of diseased plants, having the high weight of firm grain per pot comparable to the control with diseased rice plants. Moreover, there were some tolerant tillers on a diseased rice plant after treating these SAR chemicals (Figure 1). This result demonstrated that $\mathrm{CuCl}_{2}, \mathrm{~K}_{2} \mathrm{HPO}_{4}$, mixing of $\mathrm{CuCl}_{2}$ and $\mathrm{K}_{2} \mathrm{HPO}_{4}$, and oxalic acid were the effective chemicals in SAR to RGSD; among them, oxalic acid was more dominant than in lengthening the rice plant's live. This was a special phenomenon that rarely occurs in virus-infected-plants. As a result, oxalic acid was selected as one of the most effective chemicals.

Our conclusion was in accordance with the results of Tri et al. (2011). The authors showed that $\mathrm{CuCl}_{2}$ and oxalic acid helped the rice plants in decreasing the ratio of diseased plants, maintaining the weight of firm grain and increasing the activities of ribonuclease and protease inside the rice plants infected RGSD. 


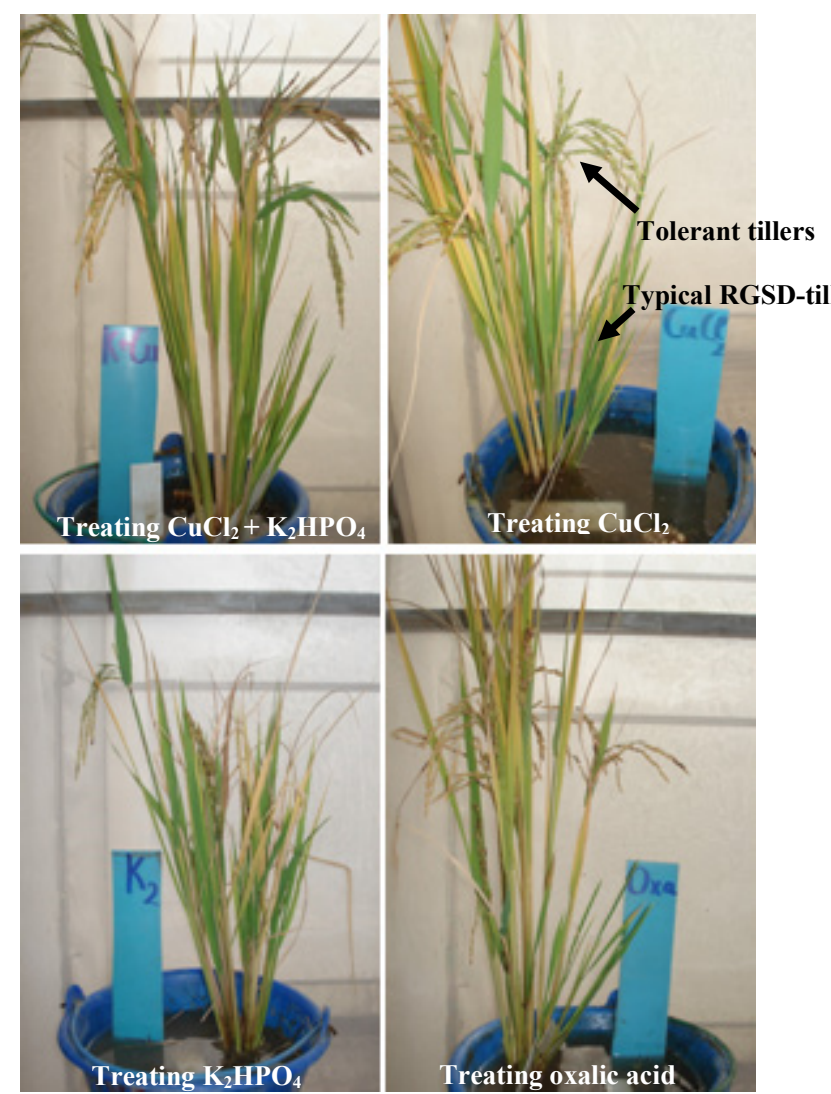

Figure 1. Rice plants at chemicals treatments

\subsection{The experiment of oxalic acid' usage on rice grassy stunt disease}

The data presented in Table 2 shows that the seed-soaking group had the ratio of infected plants at around $46.7 \%$ $63.3 \%$, significantly different in comparison with the control with diseased rice plants $(96.7 \%)$. The ratios of seed coating group had not been different to the diseased control. Therefore, soaking the seed into SAR chemicals before sowing can help the rice plant take RGSD fewer although all plants of this experiment were transmitted RGSD equally. The following leaf sprayings did not decrease the ratio of infected plants.

For average latent time, seed coating group expressed no difference in comparison with the diseased control. However, seed soaking had the ability to prolong the latent time, longer than the diseased control's time. This was an effect in inducing plants to resist viral disease.

Chemical's treatments indicated that the beginning time for diseased plants' death was over 60 days, but for the diseased control was only 36 days. Although this data could not be analysed statistically, this gap was worthy to be noticed. This result contributed to the oxalic acid's effect to induce resistance on rice. The beginning time for the diseased plants' death was from 61 to 68 days. The longest time was recorded for the seed soaking and leaf spraying at 10,20,30 and 40 DAS. As a result, the late spraying times could help the rice plant in prolonging the survival time.

At 35 DAI, the increasing rate of height of chemical treatments was equivalent and significantly different in comparison to the control with diseased rice plants. The chemical's treatments had effective tillers/pot higher than the infected control, but lower than the healthy control. There was no difference noted among these chemical treatments. The weight of firm grain /pot of oxalic acid's treatments (except seed coating) was equivalent to one of the healthy control, and higher than one of infected control. This parameter was symbolised for rice plant's yield. Therefore, oxalic acid induced rice plants, helped them maintain the yield. Among these different ways used, seed coating had the lowest effect while the others had a high effect.

Table 2. The effect of chemicals' treatment to infected rice plants' growth and yield

\begin{tabular}{|c|c|c|c|c|c|c|}
\hline Treatments & $\begin{array}{l}\text { Ratio of } \\
\text { infected } \\
\text { plants }(\%)\end{array}$ & $\begin{array}{l}\text { Average } \\
\text { latent time } \\
\text { (DAI) }\end{array}$ & $\begin{array}{l}\text { Beginning } \\
\text { time for in- } \\
\text { fected plants } \\
\text { death (DAS) }\end{array}$ & $\begin{array}{l}\text { Increasing } \\
\text { rate of } \\
\text { height at } 35 \\
\text { DAI (\%) } \\
\end{array}$ & $\begin{array}{l}\text { Effective } \\
\text { tillers/pot } \\
\text { (tiller) }\end{array}$ & $\begin{array}{l}\text { Weight of } \\
\text { firm } \\
\text { grain /pot } \\
\text { (g) }\end{array}$ \\
\hline Seed coating & $80.0 \mathrm{~cd}$ & $10.50 \mathrm{ab}$ & 61 & $45.9 \mathrm{bc}$ & 5.1 & $9.4 \quad \mathrm{bc}$ \\
\hline $\begin{array}{l}\text { Seed coating and leaf spraying at } \\
10,20,30 \text { and } 40 \text { DAS }\end{array}$ & $76.7 \mathrm{bcd}$ & $10.48 \mathrm{ab}$ & 63 & $23.8 \mathrm{c}$ & 8.3 & $12.6 \mathrm{~b}$ \\
\hline Seed soaking & $53.3 \mathrm{bc}$ & $10.94 \mathrm{~b}$ & 63 & $35.8 \mathrm{bc}$ & 6.4 & $15.8 \mathrm{~b}$ \\
\hline $\begin{array}{l}\text { Seed soaking and leaf spraying at } \\
10 \text { DAS }\end{array}$ & $46.7 \mathrm{~b}$ & $11.79 \mathrm{~b}$ & 64 & $46.0 \mathrm{bc}$ & $11.5 \mathrm{~b}$ & $19.4 \mathrm{~b}$ \\
\hline $\begin{array}{l}\text { Seed soaking and leaf spraying at } \\
20 \text { DAS }\end{array}$ & $53.3 \mathrm{bc}$ & 10.19 a & 63 & $40.6 \mathrm{bc}$ & $10.7 \quad b$ & $18.8 \mathrm{~b}$ \\
\hline $\begin{array}{l}\text { Seed soaking and leaf spraying at } \\
10,20 \text { and } 30 \text { DAS }\end{array}$ & $63.3 \mathrm{bc}$ & $11.53 \mathrm{~b}$ & 65 & $36.2 \mathrm{bc}$ & $10.9 \mathrm{~b}$ & $15.9 \mathrm{~b}$ \\
\hline $\begin{array}{l}\text { Seed soaking and leaf spraying at } \\
10,20,30 \text { and } 40 \text { DAS }\end{array}$ & $50.0 \mathrm{bc}$ & $11.07 \mathrm{~b}$ & 68 & $49.9 \mathrm{~b}$ & $10.8 \mathrm{~b}$ & $22.8 \mathrm{~b}$ \\
\hline Control with diseased rice plants & 96.7 & $9.66 \mathrm{a}$ & 36 & 0.0 & 1.6 & 2.3 \\
\hline Control with healthy rice plants & $00.0 \mathrm{a}$ & - & - & $87.5 \mathrm{a}$ & $37.7 \mathrm{a}$ & $56.8 \mathrm{a}$ \\
\hline Significant level & $*$ & $*$ & - & $*$ & $*$ & $*$ \\
\hline CV $(\%)$ & 30.4 & 36.5 & - & 7.9 & 34.0 & 36.1 \\
\hline
\end{tabular}


In general, the different usage of oxalic acid could help rice plants in maintaining the height, lengthening the survival time, increasing effective tillers/pot, especially maintaining the weight of firm grain /pot, in comparison to the diseased control. Seed soaking had better ability than seed coating in keeping rice plant's health.

However, at the field-scale applications, migratory BPHs can come into the rice fields many times. They not only arrive at the field early (at 7 DAS) but also come to later. Farmers need to protect their field at a late stage, so leaf spraying could contribute to prolong the SAR efficiency. Tuzun et al. (1986) showed that immunized plants has reduced lesion number and size compared to the nontreated controls; and, even in the absence of disease, immunized plants grew more vigorously and yield were increased up to $20 \%$, compared to the controls. Besides, Kuc (1995) reported that induced systemic resistance was not a final solution to all plant disease problems. It did deserve to be extensively and vigorously explored for its potential in providing an effective, inexpensive, natural, consumer-friendly and environmentally-friendly technology for plant disease control.

\section{Conclusion}

In conclusion, under our experimental conditions, oxalic acid seems to be a promising inducer for systemic resistance on rice to a challenge RGSV infection under nethouse conditions. The treatment - soaking the seeds into oxalic acid for 24 hours before sowing - showed better ability in SAR to RGSD than other ways of seed treatment. This result could be important in practice since it may offer a simple, environmentally safe and economically accepted mean to protect rice plants from RGSV infection and decrease the pollution by agricultural chemicals. However, additional studies are needed to confirm the results under field condition.

\section{References}

[1] Ahn, I.P., Kim, S., Lee, Y.H. 2005. Vitamin B1 functions as an activator of plant disease resistance. Plant Physiology 138:1505-1515.

[2] Al-Ani, R.A., Adhab, M.A., El-Muadhidi, M.A. and Al-Fahad, M.A. 2011. Induced systemic resistance and promotion of wheat and barley plants growth by biotic and non-biotic agents against barley yellow dwarf virus. African Journal of Biotechnology 10(56):12079-12084.

[3] Anfoka, G.H. 2000. Benzo-(1, 2, 3)-thiadizole-7carbothioic acid S-methyl ester induces systemic resistance in tomato (Lycopersicon esculentum Mill cv. vollendung) to Cucumber mosaic virus. Crop protection 19:401-405.

[4] Chirkov, A., Ina, V.I., Surgucheva, W.A., Letunova, E.V., Yuvaritsev, A.A., Tatarino, N.Y., Varlamov, V.P. 2001. Effect of chitosan on systemic Viral Infection and some Defence Responses in potato plants. Russian Journal of Plant Physiology 48(6):774-779.
[5] Chester, K.S. 1933. The problem of acquired physiological immunity in plants. The Quarterly Review of Biology 8:129-324

[6] Chithrashree, Udayashankar, A.C., Chandra Nayaka, S., Reddy, M.S., Srinivas, C. 2011. Plant growthpromoting rhizobacteria mediate induced systemic resistance in rice against bacterial leaf blight by Xanthomonas oryzae pv. oryzae. Biological control 59:114-122.

[7] Chivasa, S., Carr, J.P. 1998. Cyanide Restores N Gene-Mediated Resistance to Tobacco Mosaic Virus in Transgenic Tobacco Expressing Salicylic acid hydroxylase. Plant Cell. 10:1489-1498.

[8] Du, P.V., Bich, T.T.N., Cuong, N.D., Kim, P.V. 2001. Measurement of localized and systemic resistance of rice plant to Pyricularia grisea by foliar spray of chemical inducers. Omon rice 9:87-95.

[9] Dong, H., Beer, S.V. 2000. Riboflavin induces disease resistance in plants by activating a novel signal transduction pathway. Phytopathology 90:801-811.

[10] Edreva, A. 2004. A novel strategy for plant protection: Induced resistance. Journal of Cell and Molecular Biology 3:61-69.

[11] Elbadry, M., Taha, R.M., Eldougdoug, K.A., GamalEldin, H. 2006. Induction of systemic resistance in faba bean (Vicia faba L.) to bean yellow mosaic potyvirus (BYMV) via seed bacterization with plant growth promoting rhizobacteria. Journal of plant diseases and protection 113(6):247-251.

[12] Faheed, F.A., Mahmoud, S.Y.M. 2006. Induction of resistance in Phaseolus vulgaris against TNV by salicylic acid and kinetin. International Journal of Agriculture and Biology 8(1):47-51.

[13] Ghoshroy, S., Freedman, K., Lartey, R., Citovsky, V., 1998. Inhibition of plant viral systemic infection by non-toxic concentrations of cadmium. The Plant Journal 13(5):591-602.

[14] Govindappa, M., Umesha, S., Lokesh, S. 2011. Adathoda vasica leaf extract induces resistance in rice against bacterial leaf blight disease (Xanthomonas oryzae pv. oryzae). International Journal of Plant Physiology and Biochemistry 3(1):6-14.

[15] Heil, M. 2001. Induced systemic resistance (ISR) against pathogens - a promising field for ecological research. Perspectives in Plant ecology, Evolution and Systematic 4(2):65-79.

[16] Iwano, M. 1987. Biological control of blast disease through resistance of rice plant induced by incompatible strain of blast fungus. Annual report society plant protection North Japan 38: p. 10.

[17] Kagale, S., Marimuthu, T., Thayamanavan, B., Nandakumar, R., Samiyappan, R. 2004. Antimicrobial activity and induction of systemic resistance in rice by leaf extract of Datura metel against Rhizoctonia solani and Xanthomonas oryzae pv. oryzae. Physiological and Molecular Plant Pathology 65:91-100.

[18] Kuc, J. 1995. Induced systemic resistance - an over- 
view. IN: Induced resistance to disease in plants. Kluwer Academic Publishers. p. 169-175.

[19] Mahy, B.W.J. and Van Regenmortel, M.H.V. 2010. Desk encyclopedia of Plant and Fungal Virology, Academic Press, Elsevier Ltd, p. 613.

[20] Mandal, B., Mandal, S., Csinos, A. S., Martinez, N., Culbreath, A. K. and Pappu, H. R. 2007. Biological and molecular analyses of the acibenzolar-S-methylinduced systemic acquired resistance in flue-cured tobacco against Tomato spotted wilt virus. Phytopathology 98(2):196-204.

[21] Mayers, C. N., Lee, K. C., Moore, C. A., Wong, S. M., Carr, J.P. 2005. Salicylic Acid-Induced Resistance to Cucumber mosaic virus in Squash and Arabidopsis thaliana: Contrasting Mechanisms of Induction and Antiviral Action. MPMI 18:428-434

[22] Murphy, J.F., Zehnder, G.W., Schuster, D.J., Sikora, E.J., Polston, J.E., Kloepper, J.W. 2000. Plant growth-promoting rhizobacterial mediated protection in tomato against Tomato mottle virus. Plant Disease 84(7):779-784.

[23] Nandakumar, R., Babu, S., Viswanathan, R., Raguchander, T., Samiyappan, R. 2001. Induction of systemic resistance in rice against sheath blight disease by Pseudomonas fluorescens. Soil Biology \& Biochemistry 33:603-612.

[24] Naylor, M., Murphy, A.M., Berry, J.O., Carr, J.P. 1998. Salicylic acid can induce resistance to plant virus movement. Mol. Plant-Microbe Interact. $11: 860-868$.

[25] Pal, T.K., Bhattacharya, S., Chakraborty, K. 2011. Induction of systemic resistance in rice by leaf extract of Cymbopogan citrus and Ocimum sanctum against sheath blight disease. Archives of Apllied Science Research 3(1):392-400.

[26] Raupach, G.S., Liu, L., Murphy, J.F., Tuzun, S., Kloepper, J.W. 1996. Induced systemic resistance in cucumber and tomato against cucumber mosaic cucumovirus using plant growth-promoting rhizobacteria (PGPR). Plant Disease 80(8):891-894.

[27] Saikia, R., Kumar, R., Arora, D.K., Gogoi, D.K., Azad, P. 2006. Pseudomonas aeruginosa inducing rice resistance against Rhizoctonia solani: production of salicylic acid and peroxidases. Folia Micro- biol. 51(5):373-380.

[28] Smith, J.A., Metraux, J.P. 1991. Pseudomonas syringae pv. syringae induces systemic resistance to Pyricularia oryzae in rice. Physiological and Molecular Plant Pathology 39(6):451-461.

[29] Steiner, U., F. Schonbeck. 1995. Induced disease resistance in monocots. IN: Induced resistance to disease in plants. Kluwer Academic Publishers. p. 86-110.

[30] Sudhakar, N., Nagendra-Prasad, D., Mohan, N., Murugesan, K. 2007. Induction of systemic resistance in Lycopersicon esculentum cv. PKM1 (tomato) against Cucumber mosaic virus by using ozone. Journal of Virological Methods 139:71-77.

[31] Taheri, P., Tarighi, S. 2010. Riboflavin induces resistance in rice against Rhizoctonia solani via jasmonate-mediated priming of phenylpropanoid pathway. Journal of Plant Physiology 167:201-208.

[32] Thuy, T.T.T., Lubeck, M., Smedegaard-Petersen, V., the Neergaard, E., Jorgensen, H.J.L. 2004. Research results on rice brown spot disease (Bipolaris oryzae) in rice at Mekong Delta. Conference on induced resistance in rice. Agriculture Press. p. 51-72.

[33] Tri, N.T., Kim, P.V., Huy, T.N.T., Tam, L.T. 2011. The activities of ribonuclease and protease in systemic acquired resistance of $\mathrm{CuCl}_{2}$ and oxalic acid against rice grassy stunt virus. The $10^{\text {th }}$ National Conference of Vietnamese Phytopathological Society: 305-315 (in Vietnamese).

[34] Tuzun, S., Nesmith, W., Ferriss, R. S., Kuc, J. 1986. Effects of stem injections with Peronospora tabacina on growth of tobacco and protection against blue mold in the field. Phytopathology 76:938-941.

[35] Vietnam Plant Protection Department, 2006. Report of Plant Protection Department on situation of brown plant hopper, rice grassy stunt disease and rice ragged stunt disease. $3^{\text {rd }}$ Nov, 2006 (in Vietnamese)

[36] Zehnder, G.W., Yao, C., Murphy, J.F., Sikora, E.R., Kloepper, J.W. 2000. Induction of resistance in tomato against cucumber mosaic cucumovirus by plant growth-promoting rhizobacteria. BioControl 45:127137. 